\title{
EFFECTIVENESS OF SERVICE DELIVERY IN PUBLIC SECONDARY SCHOOLS: THE ROLE OF SCHOOL NEEDS IDENTIFICATION PROCEDURE AND TENDERING PROCESS
}

\author{
Jane Mwikali Sila ${ }^{1 \mathrm{i}}$, \\ Emily Kirwok ${ }^{2}$ \\ ${ }^{1}$ Department of Educational Management and Administration, \\ Mount Kenya University, \\ P.O. Box 342, 01000, Thika, \\ Kenya \\ 2Dr., Department of Educational Management and Administration, \\ Mount Kenya University, \\ P.O. Box 342, 01000, Thika, \\ Kenya
}

\begin{abstract}
:
Despite the Kenyan government allocation of billions of shillings to schools each year and the existing legal frameworks, service delivery has been faced with irregular procurement procedures. Thus, the purpose of the study was to investigate the effectiveness of service delivery in public secondary schools with a school needs identification procedure and tendering process perspective. Guided by the Agency Theory and Cultural Theory, the study adopted descriptive survey method design and carried out in Likoni sub-county, Mombasa. With a sample size of 116 respondents, questionnaires were administered among schools' principals, deputies, bursars and storekeepers. The instrument was examined for reliability at a correlation coefficient of .73. Data analysis entailed descriptive and inferential statistics using SPSS Version 24.0. The study findings showed that the element of needs identification plays a role in the culmination of the requirements which in turn has effect on service delivery in public secondary schools. The study also revealed that the influence of tendering process on service delivery is insignificant at level .05 and concludes that there is no significant relationship between tendering process and service delivery.
\end{abstract}

Keywords: service delivery, public schools, tendering process, needs identification, agency theory

${ }^{i}$ Correspondence: email mwikalisila@gmail.com 


\section{Introduction}

Service delivery is a concern in institutions that require appropriate decisions on sourcing for funds, expenditure control and optimal allocation of the finances guided by accountability measures. In a US study, Fung (2015) reports that the main role for service delivery in organizations is sourcing for funds, use of the funds and enhancing proper utilization of the funds. In a global view, Ogbonnaya (2010) posits that the task of service delivery in most developed countries is always aimed at ensuring efficient and effective utilization of sourced funds. This argument has the bias on the fact that resources are scarce, and the public funds are mostly collected from the poor citizens especially in developing countries like in the Sub-Saharan Africa. It is, therefore, a prudent and ethical idea that the educational administrators use the resources optimally. When this is observed, the institutional objectives are likely to be achieved. However, if the funds are mismanaged through embezzlement, misappropriations, diversion from the targets, the mission and vision of the institution remains in futility.

Worldwide, schools' head teachers are mandated to ensure school financial expenditures are handled in efficient and effective manner as spelt out in respective school management manuals (Fung, 2015). However, in many African countries including Nigeria, South Africa, Angola, and Kenya, this is the only possible way by which the required services can be delivered consistently as spelt in schools' missions and visions (Olembo, 2009). Unfortunately, this task is never taken and performed as outlined in various codes of conduct (Schools' management manual). Back in Kenya, the head teachers often underperform in financial expenditure accountabilities (Ministry of Education, 2007). Government entities have attributed this to employment of less qualified staff who are either partially trained or lack experience in effective financial records keeping for accountability.

In Kenya, the September 2015 EACC report showed that fraud in schools' procurement takes place in various forms including signatures forgery, delivery of undesired books, extra charging and possibly single sourcing of suppliers. Unfortunately, this is done by tendering committee at school level. The report also indicated cases where the required signatures for tendering committee members in the documented minutes showed differences in the signatures in the supplies order form. The report thus unearthed massive irregular tendering procedures in purchases of textbooks for public schools required the respective headteachers to take responsibility of the rackets. In its annual publications, the government encloses a list of schools' approved textbooks per subject to be used as a guide in such tendering procedures (EACC, 2015). A further investigation by the anti-graft body revealed that some head teachers handpicked their suppliers. Other head teachers tried to defend the inappropriateness by citing the distance of the supplier from the school as the identification criterion. Moreover, a significant number of schools left the supply to single supplier for a long period of time. The period stretched to as many years as eight while in one surprising scenario, a school 
had retained a supplier since the inception of FPE in 2003. Apparently, this is not unique for public secondary schools in Likoni sub-county.

According to Mito and Simatwa (2012), sham procurement forms a basis of the major challenges facing the effective management of schools. A survey carried out by Kenya Anti-Corruption Commission revealed the rot of single suppliers colluding with the school principals to get the funds in an unauthorized manner (KACC, 2010). However, the findings failed to explain the measures the government was taking to eliminate such malpractices in the procurement process in public secondary schools in Kenya. Another study by Onyikwa et al. (2013) revealed that tendering committees in secondary schools distort the regulations to restrict the participation of interested suppliers in procurement or still direct the outcome of others. This relates to school's overspending and/or funds diversion which have led to unaccountability of extra expenditures in public schools. In the same breadth, incompetent workforce in procurement, lack of proper documentations, inadequate and biased auditing and records keeping add up to the financial irregularities facing public educational institutions in Kenya today (Magak, 2013).

Financial challenges in public secondary schools in Kenya have adversely affected service delivery, and this is characterized by unprecedentedly fraudulent procurement procedures and processes (EACC, 2015). This is despite the billions of shillings allocated to these institutions by the national government each year. Against this backdrop, there are legal frameworks that are intended to guide, monitor and control the whole procurement process in school requirements (Magak,2013). Despite the government releasing over Kenya shillings 2 billion towards buying of books between 2014 and 2018 for Mombasa County, the pupil to book ratio still stood at 5:1 in schools (Government Textbook Distribution Report, 2018). With these trends, there is enough evidence that there still exist gaps in the procurement procedures in effectiveness of service delivery in these schools including Likoni Sub-county. Thus, this study sought to fill the gap of inappropriateness in procurement procedures in achieving effective service delivery in public secondary schools in Likoni Sub-county with objectives to evaluate the influence of school needs identification procedure and tendering process on effective service delivery in public secondary schools in Likoni Sub-county.

\section{Literature Review}

\subsection{Theoretical Perspective}

This study was guided by two theories - agency theory and cultural theory. The two theories relate to the study problem through association of two parties in a task and competing within a given level of power for each party. In this context, the principals and the suppliers are the parties who are carrying out a task to get school requirements in order to satisfy service delivery. 


\subsection{Agency Theory}

The theoretical framework in this study was guided by the Agency Theory as proposed by Jensen and Meckling (1976). According to this theory, an agency is made when a person (the principal) contracts another person (the agent) to carry out specified services on behalf of the principal. In the process of the contract, conflicts arise between the parties due to conflicting interests. This relates to the conflicts of interest that emerge within procurement procedures. These conflicts may directly affect service delivery of the organization to its clients. Agency theory is concerned with the intervention that can be taken to resolve the differences between the principal and agent (Kenton, 2018). This may arise because the principal is either partially informed or completely not informed of the processes and procedures that the agent is going to undertake in accomplishing the task agreed upon or basically there exists some restrictions of access to some vital information.

\subsection{Cultural Theory}

In a different dimension, Cultural Theory posits that structures of social organization give individuals powers to compete against others. This theory was founded by Mary Douglas in 1970. The theory points at possible risks that a school head (principal) and a supplier may be involved in. In the process of delivering the supplies, the supplier could be relying on the facilities of the principal to execute the agreed upon supplies. Therefore, this leaves more risk to the principal than to the supplier as the whole wear and tear processes costs will be left and met by the principal (school). This scenario is common with situations where the stakeholders are the sole source of financial support, and the external entity (supplier) is at the discretion of use of the resources especially in the public sector (Kenton, 2018). The external entity always bears lesser risk than the client as the fatalities will be left to the client.

\subsection{Empirical Literature}

It is regulated that procurement procedures should be adhered to by the procuring entity. Studies have shown that an effective procurement procedure will start with generation of requisition by the user department as a way of documenting existence of the need. Lyons (2009) posits that the process is ignited by need or a requirement. In their study, Peiffer and Rose (2016) outlined seven key elements driving the success of a procurement process. The study recommends the effectiveness in management information, clarity in procurement strategy, design of expertise, proactive approach, a corporate view, focused co-ordination and effortless give in. The researchers also recognize the importance of communication across all levels of the organisations' members involved in the procurement process. It is also necessary to set a strategy geared towards attaining the need of value for money (Peiffer \& Rose, 2016). As an entrust to the public, there is always need for clarifying all the communications confined to total cost, quality of the supplies and competitiveness among the suppliers.

Globally, public procurement is the driving force of the public services and measures of its success (Dzuke \& Naude, 2015). Some studies identified key problems in 
the public procurement system as starting at needs identification procedure stage (Licenji, 2015). Dza, Fischer and Gapp (2013) found that conflict of interest in the acquisition of supplies in schools is a real challenge in propagating the regulations governing public procurement in Africa. In developing countries, schools' requirements' identification influences the tendering procedures folding against the regulations by awarding contracts to companies and suppliers of own choices. More specifically, in subSaharan Africa, Ringwald and Ndercaj (2014) reported inadequate observing of transparency and integrity requirements in policy and process of procurement especially at the needs identification procedure stage as a major problem in procurement process.

A different study in South Africa reports that the availability and implementation of the public schools' procurement reforms together with the emphasis on supply chain management has not solved the existing challenges such as non-compliance. There are numerous cases of irregular awards of tenders against the backdrop of clear legislation and policies advocating for proper procurement and supply chain management (Ambe \& Badenhorst-Weiss, 2012). In Limpopo, unclear listing of school requirements by the government was reported to be the major challenge in the implementation of the regulations as spelt in the supply chain management section of the law (Livhuwani, 2012). In fact, the challenge does not stop with the implementation but also affects service delivery intended against the set priorities. In additional findings, the identified requisitions could not match the populations in respective schools. Some materials were identified in quantities double of what was required for their population sizes.

A survey by Musanzikwa (2013) reports a number of hurdles in schools' procurement including complex and slow decision-making on requirements, conflict of interest, and the leeway to fail to adhere to SPB procedures. The poor decision making in needs identification procedure resulted in major delays in school projects, for example, the construction of school toilets in one school on Gokwe North, took slow undertakings that resulted to taking several years to complete. Different surveys report challenges such as conflict of interest where the results showed that the school management delayed the process of needs identification procedure with personal interest to identify suppliers ahead of the needs identification procedure (Shaw, 2010).

Chimberengwa et al. (2015) faults problems in procurement process to be causes of inefficiencies in service delivery in public schools in Zimbabwe. These problems include delayed decision making, unclear committee memberships, and lack of transparency in the identification procedure. Dzuke and Naude (2015) noticed that the regulations in the legal framework are a key hurdle based on the fact that all the stipulated stages are regularized. This exists as evidence in the requirement of participatory approach to all activities including identification of requirements, approval of tenders and evaluation that should notify and inform the SPB.

The studies depict much of association between tendering process with value for money (Peffer \& Rose, 2016), leaving out the direct effect of insufficient service delivery. Value for money could mean quality which is not concerned with timelines of the deliveries. Moreover, the study by Rongwald and Ndercaji (2014) only concentrate on 
inadequacies in transparency and integrity which fails to address the service delivery needs. In other instance such as Limpopo's where lack of school requirement listing is not associated with service delivery as the tendering committee may avail the list of the needs. In addition, the report shows no link between requirement quantity and the available population. While it is known that tendering process is long and cumbersome with regular meetings required, none of the studies connect the bureaucracy and service delivery which this study tried to evaluate.

Implementation of the legal tendering procedure is the driver of those countries intending to ensure fairness in business as it confines itself to a standard law of the United Nations (MacDonald, 2008). The school procurement reforms are geared towards persuading implementation of the standard procurement law and system. Unfortunately, it lies in the public domain as a hurdle that member signatories must tolerate (Korir, Afand \& Mathenge, 2015).

Tendering committee needs to ascertain the capabilities of suppliers and ensure procured items are delivered in realistic quantities and stated terms. The technical committee is established to advise on legalities and fundamental procedures so that the process runs on up-to- date information and regulations (Republic of Kenya, 2006). Moreover, it is important to be noted that this process is only possible through ensuring participatory approach and benchmarking with other public offices that have practiced such best tendering procedures.

Tendering process considers those in charge of various strategy responsibilities as drawn from implementation; the task is to select the desirable supplier who will be part of the implementation process to make it a success. This also calls for adoption of the systems used by the particular institution (Adefolake, 2012); the most important activities to be done and the planning for the available resources for the organisation in addition to the key role played by each of the departments in the organization. This is enhanced by technological systems installed as the best way of monitoring and implementing the set systems (United Nations Development Programme, 2009). Considerations of tendering sometimes call for training of the new workforce and inducting the existing one (UNDP, 2009)

A well implemented tendering procedure in a school environment is an effective tool for implementation of the set legal framework and need to exist as tool for school governance in order to straighten the systems. Such cases also call for effective tendering procedure that in turn builds school's legitimacy. Contrary to such practices, corrupt deals in tendering process promote backwardness with emergence of societal inequality and poverty. This happens through misuse and diversion of financial resources against the planned social needs; hence, it results into wrong or fake decisions which spin unfair competition through corrupt undertakings that directly affect quality service delivery (Adefolake, 2012). In their study, Bua and Adzongo (2014) report that schools that depict ineffective systems and bribery cases are always vulnerable as the officers take away with them unethical decisions of influencing the tendering process. Characteristics such as weak school headships, traditional beliefs, school politics and general illiteracy form the 
hurdles of succeeding the desire for value for money in the entire school procurement procedures. Some surveys have shown that as simple as record keeping may sound, it is a big problem for many schools. This implies that the requirement of the ISO 9001:2008 standards is not anything to come by through the whole process of procurement. For instance, Peiffer and Rose (2016) calls for effective school administration that emphasizes on accountability, transparency and trust for improved efficiencies in the procurement process. However, the study reveals that commitment must be accompanied by a common goal for the institutions in a given surrounding to try and make the process a norm and culture for effective governance.

\section{Material and Methods}

The study adopted descriptive survey method design. The study was carried out in Likoni sub-county with a target population of 190 respondents. Using a sampling table by Bartlett, Kotrlik, \& Higgins (2001), a population of 190 gave a 116-sample size. With only 10 public secondary schools in the sub-county, all the schools' principals, deputies, bursars and storekeepers were selected using census method in the sample while the remaining 76 were the HODs. Stratified random sampling was used to select the HODs. The research instrument involved self-designed questionnaires. Pre-testing of the questionnaire was carried out with respondents in three public secondary schools in the neighboring Mvita Sub-County to ascertain reliability and validity of the questionnaire. Data analysis entailed descriptive statistics using SPSS Version 24.0. These included frequencies, percentages, means and standard deviations. Moreover, there was inferential statistics involving parametric tests in form of ANOVA. Data presentation involved tables, figures and charts.

\section{Results and Discussion}

\subsection{Influence of School Needs Identification Procedure on Effective Service Delivery}

The principal respondents were asked to rate the level of agreement with a few statements drawn from the study literature concerning procurement procedures and service delivery in their schools. The responses were ranked on a Likert-scale from 5-1 with meanings 5- strongly agree, 4- agree, 3- undecided, 2- disagree and 1- strongly disagree. The results were analyzed and presented in Table 1. 
EFFECTIVENESS OF SERVICE DELIVERY IN PUBLIC SECONDARY SCHOOLS: THE ROLE OF SCHOOL NEEDS IDENTIFICATION PROCEDURE AND TENDERING PROCESS

\begin{tabular}{|c|c|c|c|c|c|c|}
\hline Statement & $\begin{array}{c}\text { Strongly } \\
\text { agree }\end{array}$ & Agree & Undecided & Disagree & $\begin{array}{l}\text { Strongly } \\
\text { disagree }\end{array}$ & Total \\
\hline $\begin{array}{l}\text { There is a committee that } \\
\text { does needs identification }\end{array}$ & $\begin{array}{c}4 \\
(26.67 \%) \\
\end{array}$ & $\begin{array}{c}5 \\
(33.33 \%) \\
\end{array}$ & $\begin{array}{c}3 \\
(20 \%) \\
\end{array}$ & $\begin{array}{c}2 \\
(13.33 \%) \\
\end{array}$ & $\begin{array}{c}1 \\
(6.67 \%) \\
\end{array}$ & $\begin{array}{c}15 \\
(100 \%) \\
\end{array}$ \\
\hline $\begin{array}{l}\text { Committee membership is } \\
\text { inclusive }\end{array}$ & $\begin{array}{c}5 \\
(33.33 \%) \\
\end{array}$ & $\begin{array}{c}4 \\
(26.67 \%) \\
\end{array}$ & $\begin{array}{c}3 \\
(20 \%) \\
\end{array}$ & $\begin{array}{c}2 \\
(13.33 \%)\end{array}$ & $\begin{array}{c}1 \\
(6.67 \%)\end{array}$ & $\begin{array}{c}15 \\
(100 \%)\end{array}$ \\
\hline $\begin{array}{l}\text { There is required channel of } \\
\text { approval of needs identification }\end{array}$ & $\begin{array}{c}2 \\
(13.33 \%) \\
\end{array}$ & $\begin{array}{c}5 \\
(33.33 \%) \\
\end{array}$ & $\begin{array}{c}4 \\
(26.67 \%) \\
\end{array}$ & $\begin{array}{c}2 \\
(13.33 \%) \\
\end{array}$ & $\begin{array}{c}2 \\
(13.33 \%) \\
\end{array}$ & $\begin{array}{c}15 \\
(100 \%) \\
\end{array}$ \\
\hline $\begin{array}{l}\text { The Needs identification must } \\
\text { be verified by the County/SC } \\
\text { Education office }\end{array}$ & $\begin{array}{c}2 \\
(13.33 \%)\end{array}$ & $\begin{array}{c}3 \\
(20 \%)\end{array}$ & $\begin{array}{c}4 \\
(26.67 \%)\end{array}$ & $\begin{array}{c}3 \\
(20 \%)\end{array}$ & $\begin{array}{c}3 \\
(20 \%)\end{array}$ & $\begin{array}{c}15 \\
(100 \%)\end{array}$ \\
\hline $\begin{array}{l}\text { The behavior of personnel in } \\
\text { excellent schools will instill } \\
\text { confidence in students }\end{array}$ & $\begin{array}{c}3 \\
(20 \%)\end{array}$ & $\begin{array}{c}5 \\
(33.33 \%)\end{array}$ & $\begin{array}{c}6 \\
(40.00 \%)\end{array}$ & $\begin{array}{c}1 \\
(6.67 \%)\end{array}$ & $\begin{array}{c}0 \\
(0.00 \%)\end{array}$ & $\begin{array}{c}15 \\
(100 \%)\end{array}$ \\
\hline Total & $\begin{array}{c}16 \\
(21.33 \%)\end{array}$ & $\begin{array}{c}22 \\
(29.33)\end{array}$ & $\begin{array}{c}20 \\
(26.67 \%) \\
\end{array}$ & $\begin{array}{c}10 \\
(13.33 \%)\end{array}$ & $\begin{array}{c}7 \\
(9.33 \%) \\
\end{array}$ & $\begin{array}{c}15 \\
(100 \%)\end{array}$ \\
\hline
\end{tabular}

Table 1 shows that majority of the respondents $5(33.33 \%)$ agreed that There is a committee that does needs identification. On the same statement, the next majority $4(26.67 \%)$ strongly agreed with the statement. The least $1(6.67 \%)$ strongly disagreed with the statement while $2(13.33 \%)$ disagreed. This means that the element of needs identification plays a role in the culmination of the requirements which in turn has effect on service delivery in public secondary schools. This emerged from the aspect of only informed staff can deliver services. When asked on the Committee membership being inclusive, majority of the respondents 5(33.33\%) strongly agreed with the statement. For the least of the respondents $1(3.33 \%)$ strongly disagreed with the statement. On the statement, there is required channel of approval of needs identification, majority of the respondents 5(33.33\%) agreed that there was a requirement for approval with the least $2(26.67 \%)$ strongly disagreeing. For the Needs identification must be verified by the County or Sub County Education office, majority $4(46.67 \%)$ were undecided on the element in regard to service delivery. Similarly, the concern on the behavior of personnel in excellent schools will instill confidence in students scored highest at the undecided $6(66.67 \%)$. However, a close frequency of 5(33.33\%) indicated agreement with the statement. Overall, 22(29.33\%) agreed with the statements drawn in the statements' favor of service delivery in the schools.

The study findings conform to the posting of Peiffer and Rose (2016) on seven key elements driving the success of a procurement process. Their study recommended the effectiveness in management information, clarity in procurement strategy, design of expertise, proactive approach, a corporate view, focused co-ordination and effortless give in to succeed service delivery for public institutions with the emphasis of needs identifications as the basis of effective management. On the other hand, Ringwald and Ndercaj (2014) reported inadequate observing of transparency and integrity requirements in needs in the process of procurement especially at the need's identification procedure stage as a major problem in procurement process. 
The Questionnaire for Bursars, Storekeepers and HODs asked on to what extent they agreed with the following statements regarding procurement procedures and services delivery in your school. The responses were ranked on a Likert-scale with indicators 5 - very adequate, 4 - adequate, 3 - inadequate, 2 - very inadequate, 1 - not sure. The responses were analyzed using means and standard deviations and the results presented using Table 2.

Table 2: Need Identification Element and Service Delivery

\begin{tabular}{|l|c|c|}
\hline Needs Identification Element & Mean & Standard deviation \\
\hline Description of the need & 4.35 & 0.23 \\
\hline Procedure in need identification & 3.54 & 0.18 \\
\hline Needs identification initiator & 2.40 & 0.34 \\
\hline Need importance & 3.12 & 0.20 \\
\hline Need cost & 4.87 & 0.07 \\
\hline Need quantity & 2.40 & 0.34 \\
\hline
\end{tabular}

Table 2 shows that the respondents drawn from the group of bursars, storekeepers and HODs had the highest mean Likert-scale score on the Need cost at 4.87, description of the need at 4.35, procedures followed in the need identification at 3.54, the Needs importance at 3.12 while needs identification initiator and Needs quantity tying at a mean of 2.40. Of all the needs identification elements, Needs cost also led with lowest standard deviation implying greater agreement among the entire sample that indeed the Needs cost was given apriority in the whole process of identifying Needs in the public secondary schools in Likoni Sub-county. Apparently, need identification initiator and Need quantity had the highest standard deviation at .34 implying higher differences in views about the consideration of the element in the process of identifying school needs.

The results are in tandem with the findings of Korir, Afande \& Mathenge (2015) who opine that all the elements of needs identification procedure are important in the beginning stage of tendering process. Identification of the requirements goes hand in hand with procurement costs which in turn determine service delivery in each school. For Rongwald and Ndercaji (2014), concentrating on cost elements alone fails to address the service delivery needs. In other instance such as Limpopo's where lack of school requirement listing is not associated with service delivery as the tendering committee may avail the list of the needs. In addition, the report shows no link between requirement quantities and needs identification. The study revealed that the needs identification procedure of procurement is key in achieving the acquisition of the equipment need to execute important services in the schools which in turn culminate to effective service delivery.

\subsection{Influence of Tendering Process on Service Delivery}

The second objective of the study was to establish the influence of tendering process on service delivery in public secondary schools in Likoni Sub-county. The principal respondents were asked to indicate the level to which they felt that the identified 
elements of procurement were critical to the service delivery in their schools. The responses were ranked on a Likert-scale of 5-1 with the meanings attached to the numerals as 1 - Factor has no impact, 2 - Factor has a moderate impact, 3 - Factor is critical, 4 - Factor is very critical, and 5 - Factor is extremely critical. The results were analyzed. The results were analyzed and presented in Table 3.

Table 3: Tendering Elements and Service Delivery

\begin{tabular}{|c|c|c|c|c|c|c|}
\hline Factors & $\begin{array}{c}\text { Factor } \\
\text { is extremely } \\
\text { critical }\end{array}$ & $\begin{array}{l}\text { Factor } \\
\text { is very } \\
\text { critical }\end{array}$ & $\begin{array}{l}\text { Factor } \\
\text { is } \\
\text { critical }\end{array}$ & $\begin{array}{c}\text { Factor has } \\
\text { a moderate } \\
\text { impact }\end{array}$ & $\begin{array}{l}\text { Factor } \\
\text { has no } \\
\text { impact }\end{array}$ & Total \\
\hline $\begin{array}{l}\text { There's publication } \\
\text { of tenders }\end{array}$ & $\begin{array}{c}4 \\
(26.6 \%)\end{array}$ & $\begin{array}{c}5 \\
(33.3 \%)\end{array}$ & $\begin{array}{c}3 \\
(20.0 \%)\end{array}$ & $\begin{array}{c}2 \\
(13.3 \%)\end{array}$ & $\begin{array}{c}1 \\
(6.6 \%)\end{array}$ & $\begin{array}{c}15 \\
(100 \%)\end{array}$ \\
\hline $\begin{array}{l}\text { There is a given } \\
\text { time period for } \\
\text { submission of bids }\end{array}$ & $\begin{array}{c}3 \\
(20.0 \%)\end{array}$ & $\begin{array}{c}2 \\
(13.3 \%)\end{array}$ & $\begin{array}{c}4 \\
(26.6 \%)\end{array}$ & $\begin{array}{c}5 \\
(33.3 \%)\end{array}$ & $\begin{array}{c}1 \\
(6.6 \%)\end{array}$ & $\begin{array}{c}15 \\
(100 \%)\end{array}$ \\
\hline $\begin{array}{l}\text { There is a certain } \\
\text { required minimum } \\
\text { number of bids } \\
\text { before award of tender }\end{array}$ & $\begin{array}{c}5 \\
(33.3 \%)\end{array}$ & $\begin{array}{c}3 \\
(20.0 \%)\end{array}$ & $\begin{array}{c}2 \\
(13.3 \%)\end{array}$ & $\begin{array}{c}3 \\
(20.0 \%)\end{array}$ & $\begin{array}{c}2 \\
(13.3 \%)\end{array}$ & $\begin{array}{c}15 \\
(100 \%)\end{array}$ \\
\hline $\begin{array}{l}\text { The bidding process } \\
\text { is monitored and } \\
\text { verified by } \\
\text { tender evaluation } \\
\text { committee }\end{array}$ & $\begin{array}{c}2 \\
(13.3 \%)\end{array}$ & $\begin{array}{c}5 \\
(33.3 \%)\end{array}$ & $\begin{array}{c}6 \\
(40.0 \%)\end{array}$ & $\begin{array}{c}1 \\
(6.6 \%)\end{array}$ & $\begin{array}{c}1 \\
(6.6 \%)\end{array}$ & $\begin{array}{c}15 \\
(100 \%)\end{array}$ \\
\hline Total & $\begin{array}{c}14 \\
(23.3 \%)\end{array}$ & $\begin{array}{c}15 \\
(25.0 \%)\end{array}$ & $\begin{array}{c}15 \\
(25.0 \%)\end{array}$ & $\begin{array}{c}11 \\
(18.3 \%)\end{array}$ & $\begin{array}{c}5 \\
(8.3 \%)\end{array}$ & $\begin{array}{c}15 \\
(100 \%)\end{array}$ \\
\hline
\end{tabular}

Table 3 shows that majority of the respondents 5(33.3\%) felt that presence of publication tenders factor had a very critical impact with $4(26.6 \%)$ indicating an extremely critical factor. The least $1(6.6 \%)$ felt that the factor had no impact on service delivery. On a given time period for submission of bids, the majority of the respondents $5(33.3 \%)$ felt that the factor had a moderate impact while $4(26.6 \%)$ felt that the factor was critical. Similarly, only $1(6.6 \%)$ felt that the factor had no impact on service delivery. On the certain number of minimum required bids, majority $5(33.3 \%)$ felt that the factor has extremely critical impact. On this factor, the least $2(1.3 \%)$ tied at the moderate impact and no impact respectively. The process of monitoring the tender process factor was seen as of moderate impact at 6(40.0\%) followed by a higher significant frequency of 5(33.3\%) at very critical impact. Overall, majority of the respondents (15.25\%) felt that the elements had both moderate and very critical impact in service delivery.

The results form support for Bua and Adzongo (2014) report which shows that schools that depict ineffective systems and bribery cases in the tendering process are always vulnerable as the officers take away with them unethical decisions of influencing the tendering process. Characteristics such as weak school headships, traditional beliefs, school politics and general illiteracy form the hurdles of succeeding the desire for value for money in the entire tendering procedures. 
Further, ANOVA analysis was carried out using SPSS version 24.0 to determine the association between the perceived tendering procedure elements and service delivery in the schools. The results are shown in Table 4.

Table 4: ANOVA on Tendering Procedures and Service Delivery

\begin{tabular}{|c|c|c|c|c|c|c|}
\hline Model & & Sum of squares & df & Mean of squares & $\mathbf{F}$ & Sig. \\
\hline & Regression & 10.517 & 3 & 5.258 & 33.6991 & $.000^{\mathrm{b}}$ \\
\hline \multirow[t]{2}{*}{1} & Residual & 6.553 & 40 & .156 & & \\
\hline & Total & 17.072 & & & & \\
\hline \multicolumn{7}{|c|}{ a. Dependent variable: Service delivery } \\
\hline
\end{tabular}

The ANOVA Table 4 shows the analysis of variance on the two variables; tendering process as the predictor while service delivery is the dependent variable. The table shows that the regression model can be used to explain the influence of tendering process on service delivery. With $\mathrm{P}$-value $=0.000$ which is significant at $99 \%$ confidence level, $\mathrm{df}=3$ and $\mathrm{F}=33$. 6991. The coefficients of the ANOVA analysis between tendering process and service delivery were generated in the SPSS and the results shown in Table 5.

Table 5: Coefficient on Service Delivery

\begin{tabular}{|c|c|c|c|c|c|c|c|c|}
\hline \multirow[t]{2}{*}{ Model } & & \multicolumn{2}{|c|}{$\begin{array}{l}\text { Unstandardized } \\
\text { coefficients }\end{array}$} & \multirow{2}{*}{$\begin{array}{c}\begin{array}{c}\text { Standardized } \\
\text { coefficients }\end{array} \\
\text { Beta }\end{array}$} & \multirow[t]{2}{*}{$t$} & \multirow[t]{2}{*}{ Sig. } & \multirow{2}{*}{$\begin{array}{c}\text { Collinearity } \\
\text { Statistics } \\
\text { Tolerance }\end{array}$} & \multirow[t]{2}{*}{ VIF } \\
\hline & & B & Std error & & & & & \\
\hline \multirow[t]{2}{*}{1} & Constant & .280 & .742 & & .378 & .707 & \multirow[b]{2}{*}{.465} & \multirow[b]{2}{*}{2.149} \\
\hline & $\begin{array}{l}\text { Needs } \\
\text { Identification }\end{array}$ & 0.101 & .242 & .058 & .416 & .679 & & \\
\hline
\end{tabular}

a. Dependent variable: Service delivery

Using Table 5 above, the research question on what influence the tendering process has on service delivery in public secondary schools in Likoni Sub County can be deduced from the P-value (0.679) and significance level (0.05). P-value > significance level. Therefore, the influence is significant at level .05 and concludes that there is no significant relationship between tendering process and service delivery in public secondary schools in Likoni Sub-county, Kenya. These findings differ with those of Adefolake (2012) who showed that adoption of the systems used by the particular institutions in the tendering process had impact on service delivery. According to the author, tendering is an important activity to be done and the planning for the available resources for the organization in addition to the key role played by each of the departments in the organization. This is enhanced by technological systems installed as the best way of monitoring and implementing the set systems. 


\section{Recommendations}

It is evident from the findings that the procurement procedures influencing service delivery in public secondary schools in Likoni Sub-county, Kenya. Based on the findings of this study the following recommendations were made:

1) The Ministry of Education as the major stakeholders in public secondary school management should supply sufficient varieties of materials to support the head teachers' procurement initiatives. Parents, sponsors and the school community as a whole should also support the public secondary schools by providing conducive environment which help the head teachers in acquisition of procurement skills that directly or indirectly influence service delivery.

2) The ministry of education should organize for in-service training for public secondary school head teachers. In service training for head teachers is important to ensure that they keep pace with technological changes in procurement as opposed to relying on traditional handedness in delivering services that are sometimes lacking in the head teachers' immediate environment. For instance, streamlining the tendering process does not only mean using individualized and mean techniques of handling the process. But it can be extended to community involvement which enhances service delivery.

\section{Conclusion}

The study concludes that the element of needs identification plays a role in the culmination of the requirements which in turn has effect on service delivery in public secondary schools. This related from the aspect of only equipped staff can deliver services. The findings on the study objective associating schools need identification and service delivery conform to the posting of Peiffer and Rose (2016) seven key elements driving the success of a procurement process. The findings showed that majority of the respondents accepted the presence of publication tenders factor having a very critical impact which indicates an extremely critical factor. Overall, majority of the respondents support that the study elements had both moderate and very critical impact in service delivery. The results form support for Bua and Adzongo (2014) report which shows that schools that depict ineffective systems and bribery cases in the tendering process.

\section{Acknowledgements}

My sincerest heartfelt gratitude goes to my supervisor Dr. Emily Kirwok whose guidance, time and persistent motivational push saw the project being done well and on time. I appreciate the Mount Kenya University fraternity, for a wonderful learning environment and constant engagement on my scholarly welfare. Finally, my colleagues, we made it through all the blocks. I thank you for your scholarly support. To my family, your encouragement and prayers cannot be compensated in anything material, but my prayers for a long, healthy and a peaceful life are with you. 


\title{
Conflict of Interest Statement
}

The authors hereby declare that there is conflict of interest in regard to this research study and publication.

\begin{abstract}
About the Authors
Jane Mwikali Sila is a Master of Education Student in the department of educational institutions and curriculum at the university of Mount Kenya, Mombasa campus. She has been researching on the procurement procedures in public secondary schools, Likoni Sub county, Mombasa County since 2017. she received a Bachelor of Education degree from Kenyatta university in 1998. she is a teacher, hence her interest in the procuring processes in pursuit of more transparency in procurement in public educational institutions.

Dr. Emily Kirwok is a PhD holder in educational management, and currently the director Mount Kenya University, Eldoret Campus.
\end{abstract}

\section{References}

Adefolake, A. (2012). Corporate Social Responsibility of Multinational Corporations in Developing Countries: Perspectives on Anti-Corruption. Cambridge University Press

Allis, M. (2004). Service Delivery: Ratio Analysis Zerotoone Million. New York: McGrawHill.

Ambe, I. M. \& Badenhorst-Weiss, J. (2012). Procurement Challenges in the South African Public Sector. Journal of Transport and Supply Chain Management, 242-261.

Bua, F. T. \& Adzongo, P. I. (2014). Impact of Service Delivery on Secondary Schools' Administration zone a Senatorial District of Benue State-Nigeria.

Public policy and Administration Research,4(9),95-103. Budget theory. Public Administration Review 42,509-515.

Chigudu, D. (2014). Public Procurement in Zimbabwe: Issues and Challenges. Journal of Governance and Regulation / Volume 3, Issue 4

Coe, R., Waring, M., Hedges, L. \& Arthur, J. (2017). Research Methods and Methodologies in Education (2nd ed.). SAGE Publications Ltd

Creswell, J. W. (2013). Qualitative Inquiry and Research Design. Thousand Oaks, CA SAGE

Crouch, L., Winkler, D., \&RTI International. (2008). Governance, Management and Financing of Education for All: Basic Frameworks and Case Studies. Paris: UNESCO.

Eshiwani, G. (1993). Education in Kenya since Independence. Nairobi. East African Educational Publishers.

Ethics and Anti-Corruption Commission. (2015). Examination into the Disbursement and Utilization of Free Primary Funds. Nairobi: The Government Printer. 
Finstad, K. (2010). The Usability Metric for User Experience. Elsevier Journal. Interacting with Computers, 22, 323-327.

Fung, A. (2015). Putting the Public Back into Governance: The Challenges of Citizen Participation and Its Future. PAR Journal. Volume75, Issue 4, Pages 513-522

Ghauri, P. N., \& Gronhaug, K. (2005). Research Methods in Business Studies: A Practical Guide. Pearson Education.

Government of Kenya. (2013). The Basic Education Act, No.13 of 2013. Nairobi: The Government Printer.

Hausken, K. \& Ncube, M. (2017). Service Delivery Weaknesses within Education and Healthcare: Applying Empirics from Kenya, Uganda, Tanzania, and Senegal. Wiley Publishers.

Hunja, R. (2008). Obstacles to Public Procurement Reforms in Developing Countries. World Bank: Washington.

Kenya Anti-Corruption Commission. (2010). National Enterprise Survey on Corruption. Nairobi: KACC.

KACC. (2009). Public Officers Integrity Survey. Nairobi: KACC Kenya Gazette Supplement N. 92 (2006)

Kenton, W. (2018). Agency Theory: A Review. Small Business Entrepreneurship. Investopedia site

Kenya Education Management Institute.

https://www.kemi.ac.ke/index.php/about/24-history

Kiage, J. (2013). Factors Affecting Procurement Performance: A Case of Ministry of Energy. International Journal of Business and Commerce Vol. 3(1), [54-70]

Korir, S., Afande, F. \& Mathenge, M. (2015). Constraints to Effective Implementation of E-Procurement in the Public Sector: A Survey of Selected Government Ministries in Kenya. Journal of Information Engineering and Applications; Vol.5, No.4, 2015

Lyons, K. \& Gillingham, M. (2009). Purchasing and Supply Chain Management. London. MacDonald, O. (2008). Buying Power Aid Governance and Public Procurement. Ghana: Christian Aid.

Magak, O. (2013). Challenges Facing Head Teachers in Service Delivery in Public Secondary Schools: A case of Kisumu East District Kenya. Unpublished MEAP Project, University of Nairobi, Kenya.

Makori, O. (2008). The Challenges in the Implementation of the 2005 Procurement Act in the Kenya Ministry of Higher Education, Science and Technology. University of Nairobi; unpublished MBA Research Project Report.

Maronga, E., Weda, C. W., \& Kengere, D. O. (2013). An Investigation on the Influence of Government Service Delivery on Kenyan Public Secondary Schools: A Case of Sameta Division. International Journal of Scientific \& Technology Research, 2(9).

Mgbodile, T. (2010). Foundation in Educational Management and Planning. Enugu: Magnet Business Enterprise. Routledge.

Ministry of Education. (2007). Procurement Manual for Primary Schools. Nairobi: Ministry of Education. 
Mito, A. \& Simatwa, W. (2012). Challenges Faced by Newly Appointed Principals in the Management of Public Secondary Schools in Bondo District, Kenya: An analytical Study. Educational Research, 3(4), 388-401.

Musanzikwa, M. (2013). Public Procurement System Challenges in Developing Countries: The Case of Zimbabwe. International Journal of Economics, Finance and Management Sciences, 1(2), 119-127.

Nylinder, P. (2012). Budgetary Control in Public Health Care; A Study About Perceptions of Budgetary Control.

Ogbonnaya, N. I. (2010). Foundation of Education Finance. Onitsha: CAP Publishers.

Olembo J. (2009). Financing Secondary Education in Kenya. Nairobi: Bureau of Education Research.

Omar, A. (2000). A Study of the Service Delivery Techniques Practiced by Primary School Head Teachers of Changamwe Division in Mombasa Municipality.

Ouma, W. (2016). Kenya: Report Unearths Massive Fraud in Procurement of School Books. Retrieved from http://allafrica.com/stories/20160500532.html

Peiffer, C. \& Rose, R. (2016). Why Are the Poor More Vulnerable to Bribery in Africa? The Institutional Effects of Services. Journal of Development Studies, 1-12. DOI: 10.1080/00220388.2016.1257121

Public Procurement Oversight Authority (2011); Kenya, Market Price Index (4th ed.). Nairobi: Government Printer.

Rafiullah, M., Karen, D. \& Behrstock, E. (2010). Making Educational Research Relevant to Teachers: Teachers Will Use More Research When Researchers Fine-Tune How They Present Their Discoveries to Teachers. Publisher: Phi Delta Kappan, Vol. 91, No. 7, April 2010

Sharma et al., (2011). Government of India, Department of Agricultural and Cooperation, NCIPM, ICAR, New Delhi, India.

Teachers Service Commission. (2007). Revised Schemes of Service for Graduate Teachers and Lecturer. Nairobi: Teachers Service Commission.

Transparency International. (2009). National Integrity Systems: Retrieved from the TI. Source Book: www.transparency.org

The World Bank. (2013). World Development Indicators 2013. Washington DC, World Bank.

United Nations Development Programme. (2009). Handbook on Planning, Monitoring and Evaluating for Development Results. Business \& Economics

Wanyama, J. (2010). The Effectiveness of the Procurement Regulations in Kenya. Available on http://www.oecd.org

Wohlstetter Conference Centre. (2009). Increasing Accountability in American Higher Education. Retrieved from www.aei.org 
Creative Commons licensing terms

Author(s) will retain the copyright of their published articles agreeing that a Creative Commons Attribution 4.0 International License (CC BY 4.0) terms will be applied to their work. Under the terms of this license, no permission is required from the author(s) or publisher for members of the community to copy, distribute, transmit or adapt the article content, providing a proper, prominent and unambiguous attribution to the authors in a manner that makes clear that the materials are being reused under permission of a Creative Commons License. Views, opinions and conclusions expressed in this research article are views, opinions and conclusions of the author(s). Open Access Publishing Group and European Journal of Education Studies shall not be responsible or answerable for any loss, damage or liability caused in relation to/arising out of conflicts of interest, copyright violations and inappropriate or inaccurate use of any kind content related or integrated into the research work. All the published works are meeting the Open Access Publishing requirements and can be freely accessed, shared, modified, distributed and used in educational, commercial and non-commercial purposes under a Creative Commons Attribution 4.0 International License (CC BY 4.0). 